\title{
Teacher's Educational Support Services to Students with Learning Disabilities in Inclusive Educational Classrooms; The Case of Selected Secondary Grammar Schools in the South West Region of Cameroon
}

\author{
Nchia Mary-Judith Youh, PhD \\ Faculty of Education, University of Buea, Cameroon \\ Research Consultant: Foundation of Scientific Research, Community Based \\ Rehabilitation and Advocacy on Inclusive Education" (FORCAIE-Cameroon).
}

\begin{abstract}
Although there is widespread support for inclusion at a philosophical level, there are some concerns that the policy of inclusion is difficult to implement because teachers are not sufficiently well prepared and supported to work in inclusive ways. Inclusion requires teachers to accept the responsibility for creating schools in which all children can learn and feel they belong. In this task, teachers are crucial because of the central role they play in promoting participation and reducing underachievement, particularly with children who might be perceived as having difficulties in learning. The article analyzed and reviewed some of the barriers to the development of successful inclusive schools and suggests that one way of overcoming these difficulties is to reconsider the roles, responsibilities and identities of teachers. It also provides some recommendations about the role of teacher education in the development of teachers' knowledge on inclusive education.
\end{abstract}

Keywords: Teacher's Educational Support Services, Learning Disabilities and Inclusive Classrooms

\section{INTRODUCTION}

An increasing number of countries all over the world are embracing inclusive education, which has been internationally recognized as a practice for attaining equity, justice and quality education for all children, especially those who have been traditionally excluded from mainstream education such as persons with disabilities. Inclusion is a radical change within the context of Cameroon because prior to this change, the Cameroon educational system was characterized by 'the invisibility of persons with disabilities'. It is a process whose success is, among other things, strongly tied to teacher preparedness. Preparedness is used here to refer to teachers' possession of required competencies in the domains of knowledge, skills and professional dispositions or attitudes. Successful implementation of inclusive education at the level of secondary education like any other change, according to Micheal Fullan (2001), requires preparedness on the part of those charged with the responsibility of making it effective. Inclusion is a very broad concept.

\subsection{Background to the Study}

The Republic of Cameroon has enacted various pieces of legislation and signed international conventions aimed at ensuring quality secondary education for all regardless of personal background. Having policies in place is a logical and commendable first step. One of the next logical things to do is to ensure that those charged with implementation possess appropriate profiles in the dimensions of knowledge, skills and professional attitudes. In support of the above view, Swart, Engelbrecht, Eloff and Pettipher (2002), state that in addition to legislation and policies, teachers must be prepared or else inclusive education and quality education for all will not be attained.

The government of the Republic of Cameroon is committed to the provision of quality education services, at least at the level of basic and secondary education as reflected in relevant legislation. For example, Law No. 83/13 of July, 1983 relating to the protection of persons with disability, and its Decree of application No. 90/1516 of 26 November, 1990, makes up Cameroon's legal and policy implementation framework relating to the inclusion of children with disabilities. According to the 1983 law, all forms of discrimination against persons with disabilities are prohibited. 
Law No. 98/004/of 14 April, 1998 to lay down guidelines for basic, secondary and teacher education in Cameroon, describes teachers as the guarantors of quality education. For teachers to effectively shoulder this responsibility (guarantee quality education) they themselves must be of the best possible quality before and during service. To add, section 35 of 98/004, further states that "the physical and moral integrity of students shall be guaranteed within the educational system. Consequently, all forms of discrimination shall be proscribed" (Tambo, 2000, 2003). Paragraph 9 of the 1996 Constitution of the Republic of Cameroon does not only reinforce the provision of Law No. 98/004 but goes ahead to states that, "the State shall guarantee the child's right to education". The best approach to take as far as inclusive education is concerned would be to equip regular teachers with appropriate knowledge, skills and attitudes in order for them to make the learning environment responsive to students' uniqueness (Nel, 2007).

The most recent law enacted is that of 13th April 2010, relating to the Protection and Welfare of Disabled Persons.This law emphasises the prevention of disabilities, readaptation, socio-economic and political inclusion of Persons with disabilities (PWDs) and provides for penal measures for violations. Significantly, it provides for the right to an inclusive education for CWDs, and the right to 'special' education for PWDs. In addition, Cameroon is signatory to many international conventions such as the 1989 United Nations (UN) Convention on the Rights of the Child (UNCRC) - which guarantees the right to receive quality education without discrimination on any grounds. and the 1994 Salamanca Statement and Framework for Action on Special Needs Education, which recommends the inclusion of all children in regular schools regardless of their physical, intellectual, social, emotional, linguistic or other conditions.

What remains a worry is whether teachers in public schools are prepared to shoulder this responsibility. In spite of the fact that teachers are a critical component to creating inclusive classrooms that allow children with disabilities to learn and thrive, their preparation for inclusive education, has not been mentioned in the legislation. To prove the importance of teachers' preparedness for inclusion, The Salamanca Statement and Framework for Action (1994, p. 27) has also identified the knowledge and skills teachers need to possess in order to be effective in providing educational support services to students with disabilities, including those with LD in inclusive settings. Against this backdrop of enabling legislation, as (Titanji, 2008) puts it, Cameroon needs to shift its focus in the direction of issues of implementation. One of the tasks of implementation is to make sure that secondary education teachers are prepared for related challenges. Many experts feel that, in order to provide effective inclusive education for all students, regular teachers need to develop a different set of skills and knowledge than was traditionally required by the profession (Yuh \& Shey, 2008; Schumm \& Vaughn, 1995; and Baker \& Zigmond, 1995).

\subsection{Statement of the Problem}

The legislative framework in place recognizes the need to safeguard the right to education for all students, including those with learning disabilities (Titanji, 2008). Students enrolling into secondary schools are increasingly diverse because of national and international education policies such as the Education for All (EFA), and Universal Primary Education (UPE) at the level of basic education. Among these students are a constantly increasing number of students with disabilities, particularly those with learning disabilities (Tchombe, 2014). Although the expected legislation represents a major step forward in the transformation and democratization of the Cameroon educational system, not much research (to the best of this researcher's knowledge) has been carried out on the preparedness of teachers to provide support services to students with learning disabilities within inclusive settings in Cameroon. Empirical evidence from other parts of the world suggest that regular education teachers are not adequately prepared to teach students with disabilities, including those with learning disabilities in inclusive settings (Covell, 2001; Pearson \& Chambers, 2005).

Could this be the same with teachers in Cameroon? Since inclusive practices in many countries are demonstrating that teaching all students in general education settings can be done successfully if appropriate practices and methods are used (Banerji \& Daily, 1995), teacher preparedness becomes a worthwhile area for research. This is more so because variations in contexts caution against the generalizability of findings or practices. Thus it is possible that inclusive practices in government secondary grammar school classrooms in Cameroon may not be effective experiences for most teachers with logical negative consequences on students and the sustainable development efforts of the government as contained in its Growth and Employment Strategy Paper (2010-2020). The 
problem that this study seeks to address can be put into a question form as follows: Do teachers possess relevant knowledge, skills and professional attitudes to provide quality educational services to secondary school students with learning disabilities in inclusive classrooms? Answering this question is critical to efforts aimed at providing quality educational support services to all learners in inclusive settings. It is hoped that the findings would lead to actions aimed at strengthening the quality of teachers.

\subsection{Objective of the Study}

$>$ To find out the extent to which government secondary grammar school teachers are equipped with relevant knowledge to provide educational support services to students with Learning Disabilities in inclusive settings.

\section{TheORETICAL RefLections}

Two theories form the theoretical foundation of this study. These include the change theory and the self-efficacy theory.

\subsection{Change Theory}

Among experts in the field of inclusive education, there seems to be a general agreement that for regular teachers to be prepared to provide ESS to students with learning disabilities (LD) in inclusive settings, they need to change their knowledge, skills and attitudes. These experts (Bender, Vail, \& Scott, 1995; Cook, 2001; Jordan \& Stanovich, 2003; Jordan \& Stanovich, 2004) are also of the view that the successful implementation of inclusion education depends largely on the knowledge, skills and especially attitudes general education teachers have about and toward teaching students with disabilities in general and learning disabilities in particular. Literature on the change process is therefore relevant for teachers' preparedness to provide ESS to students with LD in inclusive settings, because it brings out pertinent issues that need to be acknowledged and addressed. Change is a process that involves doing things differently and taking some amount of risk.

\subsection{Self-Efficacy Theory}

The origin of self-efficacy theory can be traced to Bandura's social cognitive theory, developed in 1977. According to Bandura (1977), a person's attitudes, abilities, and cognitive skills encompass what is known as the self-system. This system plays a major role in the way teachers perceive situations such as providing educational support services to students with learning disabilities in inclusive settings and their attitudes toward them. He defines self-efficacy as "the belief in one's capabilities to organize and execute the courses of action required to manage prospective situations." Based on the social learning theory, self-efficacy beliefs influence the motivation that people have for carrying out tasks. If people perceive that the result of an activity will be negative, they are less likely to engage in that activity, while they are more likely to engage in activities in which they foresee good results; this is referred to as outcome expectancy (Bandura, 1997; Pajares, 2003). Bandura (1994) states that, these beliefs determine how people think, behave, and feel.

Although it is likely that confidence is one of many variables that influence teachers' effectiveness in the classroom, experts in the field (Pajares, 1992) indicate that teacher confidence is an important mediator in determining how teachers provide ESS to students with LD in inclusive settings. Bandura, 1986; Gibson \& Dembo, 1984, describe confidence, or self-efficacy as the teacher's judgment of his/her ability to execute successfully a behaviour required to produce certain outcomes. Such beliefs are thought to be an important moderator between teachers' knowledge and skills, and their behaviours (Emmer \& Hickman, 1991). To Gibson and Dembo (1984), confident teachers tend to maintain the attention of students with disabilities on academic activities more effectively than teachers who lack confidence in their teaching abilities. In addition, less confident teachers appear more vulnerable to provide ESS to students with disabilities in their classrooms: employing less effective strategies to support them compared with confident teachers (Evans \& Tribble, 1986).

Gibson and Dembo (1984), bring out the two components of self-efficacy: efficacy expectations and outcome expectancy. Efficacy expectations are the beliefs belonging to one's personal capacity to perform a behaviour, task or skill, while outcome expectancy is the general belief that behaviour will result in a particular outcome (Bandura, 1986; Gibson \& Dembo, 1984; Guskey \& Passaro, 1994). Therefore, behaviour is thought to be influenced not only by the belief that a particular action will 
lead to desirable outcomes, but also by the belief that one has the ability to perform that action. For example, if a teacher does not believe that he/she has the necessary knowledge and skills to perform a task - providing ESS to students with learning disabilities - he/she will not initiate or engage in the relevant behaviours, or according to Bandura (1986) persist in difficult situation. The importance of self-efficacy in understanding teacher behaviours, and efficient practices in inclusive classrooms has been highlighted through research (Gibson \& Blandford 2005; Guskey \& Passaro, 1994; Welch, 1995).

According to these researchers, teachers tend to put more effort into tasks in which they believe they will be successful than they do for those in which they anticipate failure; in this way perceptions influence the actual outcomes. Therefore, a teacher's efficacy and outcome expectations directly impact the effort and actions he/she will take in preparation to provide ESS to students with LD in his or her classroom. By having more positive expectations, the teacher is likely to put more effort in supporting all learners in inclusive classrooms, so that positive academic and social outcomes for all students particularly those with learning disabilities can be achieved.

According to Bandura's theory, self-efficacy is not a fixed trait, but changes all the time with experience (Bandura, 1997). This means that the more regualar teachers provide ESS to students with LD in their classrooms, the more they develop the confidence in doing so. The theory has outlined four factors that can influence self-efficacy and these are: mastery experiences, social modeling, social persuasion, and psychological responses.

\subsection{Knowledge, Skills and Attitudes and Provision of Educational Support Services to Students with Learning Disabilities}

Hay, Smith, and Paulsen (2001), carried out a cross-sectional survey of regular teachers in South Africa with the intention of finding out the level of their preparedness in the areas of their knowledge, skills and attitudes to provide educational support services to students with disabilities, including those with LD in inclusive settings. The results they got from their study revealed that regular teachers did not feel equipped with relevant knowledge, skills and attitudes for the task of providing educational support services to all students including those with learning disabilities in inclusive settings. The common explanation got from the result was either that they had not had training at all or had not receive sufficient training to deal with inclusive issues during their preservice or in-service training programmes. Out of a total population of 2577 respondents, only 245 felt they were equipped to function effectively in providing support services to all students in inclusive setting, while 2332 felt they were not.

Ackah (2007), also carried out a cross-sectional descriptive research in the Cape Coast Metropolis. The purpose of the study was to investigate and get a better understanding of teachers' attitudes towards the provision of educational support services to diverse students in inclusive settings. This was in order to determine their level of preparedness to effectively provide support to all students including those with learning disabilities in inclusive classrooms. Unlike the study of Hay et al. (2001), which focused on three domains - knowledge, skills and attitudes, his was limited to teachers' attitudes. The sample comprised of 132 teachers drawn from 16 schools. Data from the teachers was collected through a questionnaire and follow up interviews which provided an opportunity to cross check and further explore issues in an attempt to validate the questionnaire data that had been collected. The results showed that teachers' attitudes were mostly negative, supporting previous studies on teachers' attitudes in other countries such as United Kingdom (UK), and United States of America (USA) among others. The reason given for teachers' negative attitude was as a result of lack of training on inclusive practices.

Avramidis, Byliss and Burden (2000), also carried out research to determine the preparedness of practicing UK teachers' attitudes at both the primary and secondary levels towards teaching learners with disabilities (LD) in inclusive settings. The sample comprised of 81 trainee teachers. The results revealed that teachers who had experienced inclusive practices had positive attitudes towards inclusive education and those who lacked knowledge about inclusion displayed negative attitudes towards the provision of support services to learners with disabilities. Similarly, Bronnlee and Carrington (2000), carried out a study to examine the attitudes of pre-service teachers towards their preparedness to teach students with disabilities (LD) in inclusive settings. The findings also revealed that teachers who had direct contact with a person with a specific disability produced higher levels of comfort and more positive attitudes towards individuals with disabilities. 
A study carried out by Titi (2012), was to investigate the level of preparedness of regular school teachers from the Mthatha District on their ability to provide educational support services to students with disabilities, especially those with learning disabilities in their classrooms. Preparedness was investigated in the domains teachers' knowledge and attitudes toward providing ESS to students with disabilities, in inclusive classrooms.

A random sample of 100 teachers was selected from secondary schools that have been converted to full service schools under the Department of Education in the Mthatha District. A pre-designed, structured questionnaire was used to collect data. Data was analyzed qualitatively through thematic analysis and quantitatively through the use of the Statistical Package for the Social Sciences (SPSS). The findings revealed that sixty percent of the participants were comfortable with the provision of educational support services to students with disabilities because of previous training and experience they had had.

However, they felt that more could be done by government to support them so that inclusive education can be implemented successfully. The perception was that inclusive education was simply added to their existing workload. Forty percent of the participants were not ready for inclusive education owing to the following factors: lack of pre/in-service training, lack of resources, lack of experience and insufficient information on inclusive education.

In a recent research carried by Hansen (2013), to find out the perceptions of community college teachers regarding their preparedness to provide ESS to students with learning disabilities (LD) were investigated using a mixed-methods approach. A number of 424 teachers from a large community college in South Western Ontario made up the population. The Teacher Preparedness Questionnaire was developed to measure teachers' knowledge and attitudes regarding students with learning disabilities. Follow-up interviews with 12 participants provided qualitative data. Results showed that despite moderately positive scores on both the attitude and knowledge scales teachers generally felt unprepared for the task of providing ESS to students with learning disabilities

\section{RESEARCH METHODOLOGY}

\subsection{Research Design}

This study used a cross-sectional survey design. Cross-sectional surveys have been described as snapshots of the populations about which they gather data. The advantage they have is that they can be conducted using any mode of data collection, such as, telephone interviews, face-to-face interviews, mailed questionnaires, other self-administered questionnaires, electronic mail, Web data collection, among others. Another advantage is that there is no attempt to control conditions or manipulate variables; surveys do not allocate participants into groups or vary the treatment they receive. Surveys are well suited to descriptive studies, but can also be used to explore aspects of a situation, or to seek explanation and provide data for testing hypotheses. Therefore, to understand the opinion of teachers regarding their preparedness to provide educational support services (ESS) to learners with learning disabilities in inclusive settings the researcher found the choice of a descriptive survey appropriate.

\subsection{Study Area}

This study was carried out in some selected secondary grammar schools within the South West Regional Delegation of Secondary Education. South West Region is one of the ten administrative regions of Cameroon and makes up the two English Speaking (Anglophone) regions of the country. It is found in the coastal region of the country and is divided into six administrative divisions: Fako, Meme, Ndian, Lebialem, Manyu and Kupe Mwanenguba Divisions. Two urban areas are found in this region - Limbe in Fako and Kumba in Meme divisions. Fako Division is the seat of the regional headquarters of the South West Region.

From the perspective of the Ministry of Secondary Education, secondary education in Cameroon is supervised by inspectorates of pedagogy placed under the Regional Delegations of Secondary Education. In the South West Region, their base is Buea and these inspectorates of pedagogy are made up of regional pedagogic inspectors (RPIs) for all the subjects taught in secondary schools and their responsibility is to ensure that teachers in all the secondary schools in the region are effectively carrying out their classroom practices. For the 2014/2015 academic year, the region had 9 inspectorates of pedagogy and 116 pedagogic inspectors. 


\subsection{Population of the Study}

The population for this nstudy included all government secondary grammar school teachers and all regional pedagogic inspectors of secondary grammar schools in the South West Region. Tables 5 and 6 represent the targeted population of the study - 56 pedagogic inspectors ( 21 males and 35 females) and 3012 teachers (2110 females and 1702 males).

The accessible population on the other hand refers to the population which the researcher has access to (Amin, 2005). In this study, it encompassed all government secondary grammar school teachers in two divisions (Fako and Meme) of the South West Region. Table 7shows the accessible population 2719 teachers (1330 males and 1389 females) in 73 schools located in two divisions of the South West Region.

\subsection{Sample and Sampling Techniques}

A sample is a portion of a population that has been carefully selected and taken as being representative of the population that is studied (Fraenkel \& Norman, 2000) and sampling on the other hand, is a process of selecting a portion (sample) of the larger population that is similar in its traits distribution of the larger population. Thus the sample population consisted of all the 56 regional pedagogic inspectors (21 males and 35 females) of secondary grammar subjects in South West Region (as revealed on table 4) and 370 government secondary grammar school teachers (165 males and 205 females) selected from the accessible population of 2917 teachers (1330 males and 1387females).

Table1. Distribution of Accessible and Sample population of the study

\begin{tabular}{|c|c|c|c|c|c|c|c|c|c|}
\hline \multicolumn{5}{|c|}{ Accessible population of the study } & \multicolumn{5}{|c|}{ Sample population of the study } \\
\hline \multirow[t]{2}{*}{$\mathbf{S} / \mathbf{N}$} & \multirow[t]{2}{*}{ Division } & \multirow[t]{2}{*}{$\begin{array}{l}\text { Number } \\
\text { of schools }\end{array}$} & \multicolumn{2}{|c|}{$\begin{array}{c}\text { Number of } \\
\text { teachers }\end{array}$} & \multirow[t]{2}{*}{ Total } & \multirow[t]{2}{*}{$\begin{array}{l}\text { Number } \\
\text { of schools }\end{array}$} & \multicolumn{2}{|c|}{$\begin{array}{c}\text { Number of } \\
\text { teachers }\end{array}$} & \multirow[t]{2}{*}{ Tota } \\
\hline & & & Males & Females & & & Males & Females & \\
\hline 1. & Fako & 30 & 815 & 1087 & 1902 & 2 & 83 & 113 & 196 \\
\hline 2. & Meme & 42 & 515 & 302 & 817 & 2 & 82 & 92 & 174 \\
\hline Total & $\mathbf{0 2}$ & 72 & 1330 & 1389 & 2719 & 4 & 165 & 205 & 370 \\
\hline
\end{tabular}

The distribution of the sampled population (teachers) of the study is shown on table 1 .

Table2. Distribution of sampled number of Teachers

\begin{tabular}{|l|l|l|l|}
\hline S/N & Division & School & Teachers \\
\hline 1. & Fako & GBHS Limbe & 100 \\
& & GHS Limbe & 96 \\
\hline 2. & Meme & CCAS Kumba & 95 \\
& & GBHS Kumba & 79 \\
\hline Total & $\mathbf{0 2}$ & $\mathbf{0 4}$ & $\mathbf{3 7 0}$ \\
\hline
\end{tabular}

Table 2 shows the number of teachers targeted for the study - 370 - from the accessible population of 2719 shown on table 7 .This means that the total sample for this study was made up of 56 inspectors and 370 teachers giving a total of 426 subjects. The sample size was judged suitable based on the guidelines givin by Krejcie \& Morgan's table in Amin, (2005).

\subsection{Sampling Techniques}

The purposive, random, convenience and snowball sampling approaches were used. To select the two divisions for investigation in this study, the convenience sampling was used. These divisions were more accessible to the researcher than the others. The choice was also purposive because the two urban areas of the region are found within these two divisions (Limbe and Kumba). Thus they form cases that would provide rich data for the issues under study. This researcher also judged that the divisions were representatives of the region in terms of the number of schools and quantity of teachers (see table 6). Another reason for selecting these two divisions was the insurance of the available of teachers in the field to respond to the questionnaire as well as people to assist in data collection and analysis (Blanche et al., (2006).

To select the number of schools used in this study, two complementary sampling techniques were employed. There were the probability (simple random sampling) and non-probability (purposive sampling). Regarding the purposive sampling technique used, the criteria were that the school must be a government secondary grammar school and located in the urban area of each division. This was 
Teacher's Educational Support Services to Students with Learning Disabilities in Inclusive Educational Classrooms; The Case of Selected Secondary Grammar Schools in the South West Region of Cameroon

based on the researcher's assumption that government secondary schools were more likely than private ones to have teachers who are graduates of Higher Teacher Training Institutions (abbreviated in French as ENS) and that schools found in urban areas of the divisions would provide rich data for the problem under study (Kemper, Stringfield \& Teddlie, 2003). The schools that met all the conditions outlined above were then selected through random sampling technique. The sampling procedures, sample composition, size and representation of the study, indirectly or directly influenced the researcher's choice of the methods of information gathering as will be presented in the next section.

\subsection{Instruments for Data Collection}

The instruments used to collect data in this research were questionnaires and interview schedules. The instruments were constructed based on information from a critical review of literature and more specifically variables contained in the research questions and the problem statement.

\subsection{Validity and Reliability of Research Instruments}

Validity refers to the degree or extent to which an instrument measures what it claims to measure (Mbua, 2003). Shaughnessy, Zechmeister and Zechmeister (2003), state that validity refers to the truthfulness of a measure; whether it measures what it intends to measure. Many methods were used in this study to ensure that the questionnaires were valid. According to Mbua (2003), for an instrumemt to be reliable, it must be consistent in measurement that is, yielding the same results from time to time under the same conditions. In order to check reliability of the questionnaire for pedagogic inspectors and the questionnaire for teachers which is one of the purposes of pilot-testing, the Cronbach's Alpha reliability test was employed. Table 8 and table 9 present the results of the test.

\subsection{Pilot Study}

Conducting a pilot test is an important step before attempting the major study. This is because pilot testing gives the researcher an opportunity to identify and address the possible limitations inherent in the instrument beforehand (Fouche \& Delport cited in De Vos, 2005). Gray (2004), further states that unlike interview schedules, questionnaires cannot be edited during the actual data collect stage. It is therefore important to pilot-test them, so that they are accurate, unambiguous and easy to complete. For this study, the terms of reference included aspects such as the content and organization, effective use of the language, clarity of instruction and accuracy. The questionnaires were pretested using 4 pedagogic inspectors and 8 teachers who were not part of the study.

Result of the pilot testing revealed that respondents had no difficulties in responding to the questionnaires items. They were comfortable with the language and the length of the instrument.

\subsection{Methods of Data Analyses}

Interviews were analyzed using the process of thematic analysis whereby concepts or ideas were grouped under umbrella terms or key words (see tables 28, 29, 30, 31). As for the quantitative data, a pre-designed EpiData Version 3.1 (EpiData Association, Odense Denmark, 2008) database which has in-built consistency and validation checks was used to enter the data. Further consistency, data range and validation checks were also performed in SPSS version 21.0 (IBM Inc., 2012) to identify invalid codes. Data were essentially made up of categorical variables and they were analyzed using frequency and proportions and Multiple Response Analysis to aggregate responses within conceptual components. Reliability analysis was computed using Cronbach's Alpha Reliability Text. Chi-Square test of equality of proportion was used to compare proportions for significant differences. Association or relationship between two variables was assessed using Chi-Square test. Data were presented using frequency tables, charts and code-grounding-quotation tables. All statistics was presented at the $95 \%$ Confidence Level (CL), Alpha $=0.05$.

\section{FINDINGS}

\subsection{Analysis of Data Relating to Teachers' Knowledge}

Research question: To what extent do government secondary grammar school teachers possess relevant professional knowledge to provide educational support services to students with learning disabilities in inclusive settings? 
Nchia Mary-Judith Youh

Table3. Knowledge of concepts related to the teaching of students with $L D$

\begin{tabular}{|l|l|l|l|l|l|l|}
\hline \multirow{2}{*}{ Concept } & \multicolumn{2}{c|}{$\begin{array}{c}\text { Teachers } \\
\text { (N=243) }\end{array}$} & \multicolumn{2}{c|}{$\begin{array}{c}\text { Inspectors } \\
\text { (N=40) }\end{array}$} & \multicolumn{2}{c|}{$\begin{array}{c}\text { Total } \\
\text { (N=283) }\end{array}$} \\
\cline { 2 - 8 } & $\mathrm{n}$ & $\%$ & $\mathrm{~N}$ & $\%$ & $\mathrm{~N}$ & $\%$ \\
\hline Inclusive education & 24 & 9.9 & 18 & 45.0 & 42 & 14.8 \\
\hline Learning disability & 38 & 15.6 & 9 & 22.5 & 47 & 16.6 \\
\hline Individual education plan & 78 & 32.1 & 11 & 27.5 & 89 & 31.4 \\
\hline Special school & 148 & 60.9 & 29 & 72.5 & 177 & 62.5 \\
\hline Special teacher & 150 & 61.7 & 29 & 72.5 & 179 & 63.3 \\
\hline Assistive technology & 56 & 23.0 & 12 & 30.0 & 68 & 24.0 \\
\hline Special education & 111 & 45.7 & 26 & 65.0 & 137 & 48.4 \\
\hline Support services & 17 & 7.0 & 4 & 10.0 & 21 & 7.4 \\
\hline Differentiated instruction & 31 & 12.8 & 5 & 12.5 & 36 & 12.7 \\
\hline Curriculum adaptation & 29 & 11.9 & 15 & 37.5 & 44 & 15.5 \\
\hline Aggregated Score (MRS) & 682 & 28.1 & 158 & 39.5 & 840 & 29.7 \\
\hline
\end{tabular}

Based on the statistics on table 3, in aggregate, very few teachers out of the majority of them $(28.1 \%$; $\mathrm{n}_{\text {responses }}=682$ ) had a good understanding of the concepts related to the provision of educational support services to studentss with learning disabilities in inclusive settings. Out of the 10 concepts, a majority of teachers understood only 2 of them and the concepts were special school $148(60.9 \%)$ and special teacher $150(61.7 \%)$. On the part of inspectors, in aggregate, they were 39.5\% (MRS: $\mathrm{n}_{\text {responses }}$ $=158$ ) who had a good understanding of the concepts related to the provision of educational support services (ESS) to learners with learning disabilities. Out of the 10 concepts the majority of pedagogic inspectors were knowledgeable only on 3 of them and they were special school, special teacher and special education.

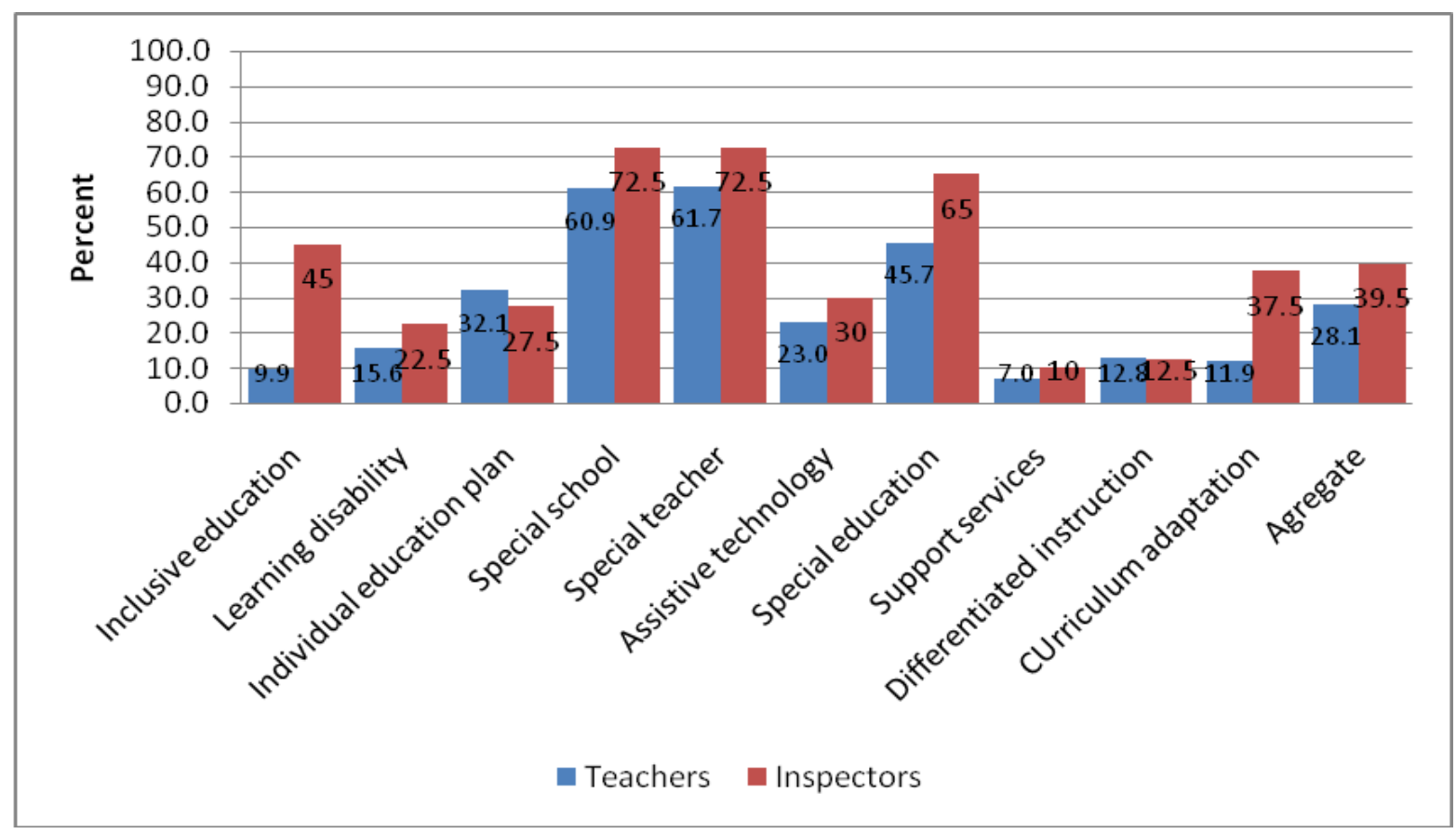

Figure2. Knowledge of concepts related to provision of ESS to students with LD

Comparing the understanding of the concepts related to the provision of educational support services to secondary school students with learning disabilities in inclusive classrooms between teachers and inspectors, figure 2 clearly revealed that inspectors were relatively more knowledgeable, with an aggregate proportion of $39.5 \%$ as against $29.1 \%$ for the teachers. Inspectors obviously understood the concept of curriculum adaptation with a higher proportion of $15(37.5 \%)$ as against $29(11.9 \%)$ for the teachers, the concept of special education with a higher proportion of $26(65.0 \%)$ as against 111 (45.7\%) for the teachers and the concept of inclusive education with a higher proportion of 18 $(45.0 \%)$ as against $24(9.9 \%)$ for the teachers. 
Teacher's Educational Support Services to Students with Learning Disabilities in Inclusive Educational Classrooms; The Case of Selected Secondary Grammar Schools in the South West Region of Cameroon

Table4. Knowledge of concepts related to the teaching of students with learning disabilities by background indicators

\begin{tabular}{|c|c|c|c|c|c|}
\hline \multirow[t]{2}{*}{ Indicators } & \multirow[t]{2}{*}{ Categories } & \multicolumn{2}{|c|}{$\begin{array}{c}\text { Knowledge of concepts related } \\
\text { to the teaching of students with } \\
\text { learning disabilities } \\
\text { (Aggregated score: } \text { MRS) }\end{array}$} & \multirow[t]{2}{*}{$\mathbf{N}_{\text {responses }}$} & \multirow[t]{2}{*}{$\chi 2$-test } \\
\hline & & Yes & No & & \\
\hline \multirow[t]{2}{*}{ Gender } & Male & $337(31.2 \%)$ & $743(68.8 \%)$ & 1080 & \multirow{2}{*}{$\begin{array}{l}\chi 2=0.27 \\
\mathrm{df}=1 \\
\mathrm{P}=0.603\end{array}$} \\
\hline & Female & $503(28.7 \%)$ & $1247(71.3 \%)$ & 1750 & \\
\hline \multirow[t]{3}{*}{ Qualification } & DIPES I/PCEG & $246(28.0 \%)$ & $634(72.0 \%)$ & 880 & \multirow{3}{*}{$\begin{array}{l}\chi 2=1.20 \\
\mathrm{df}=2 \\
\mathrm{P}=0.547\end{array}$} \\
\hline & DIPES II/PLEG & $560(31.3 \%)$ & $1230 ` 68.7 \%)$ & 1790 & \\
\hline & B.A & $34(21.3 \%)$ & $126(78.8 \%)$ & 160 & \\
\hline \multirow{3}{*}{$\begin{array}{l}\text { Teaching/working } \\
\text { experience } \\
\text { categorized }\end{array}$} & $2-5$ & $217(26.1 \%)$ & $613(73.9 \%)$ & 830 & \multirow{3}{*}{$\begin{array}{l}\chi 2=0.63 \\
\mathrm{df}=2 \\
\mathrm{P}=0.731\end{array}$} \\
\hline & $6-10$ & $240(32.0 \%)$ & $510(68.0 \%)$ & 750 & \\
\hline & $11+$ & $383(30.6 \%)$ & $687(69.4 \%)$ & 1250 & \\
\hline \multirow[t]{2}{*}{ Categories } & Teachers & $682(28.1 \%)$ & $1748(71.9 \%)$ & 2430 & \multirow{2}{*}{$\begin{array}{l}\chi 2=2.38 \\
\mathrm{df}=1 \\
\mathrm{P}=0.123\end{array}$} \\
\hline & Inspectors & $158(39.5 \%)$ & $242(60.5 \%)$ & 400 & \\
\hline
\end{tabular}

It was realized that males with a proportion $31.2 \%\left(\mathrm{n}_{\text {responses }}=337\right)$ were relatively more knowledgeable than the females with a lower proportion of $28.7 \%\left(\left(\mathrm{n}_{\text {responses }}=503\right)\right.$, that holders of DIPES II/PLEG were more knowledgeable with a weight of $31.3 \%$ ( $\left.\mathrm{n}_{\text {responses }}=560\right)$ followed by holders of DIPES I/PCEG $28.0 \%\left(\mathrm{n}_{\text {responses }}=246\right)$ and at least holders of BA $21.3 \%\left(\mathrm{n}_{\text {responses }}=34\right)$. As seen on table 15, inspectors were more knowledgeable than the teachers. In a nutshell, though some discrepancies were observed, the understanding of the concepts related to the provision of ESS to learners with LD was not significantly dependent on gender, working experience and category of educators $(\mathrm{P}>0.05)$.

\subsection{Perceived Teachers' Knowledge to Provide Educational Support Services to Students with Learning Disabilities in Inclusive Settings}

Out of the 19 indicators that made up the conceptual component 'knowledge in providing ESS to students with learning disabilities in inclusive settings', a majority of teacher were knowledgeable only in 6 of them and the indicators were 'The purpose of assessment is to enrich both teacher instruction and students' learning' 183 (75.3\%), 'That the data help me plan for next steps in students' learning' 174 (71.6\%), 'That students with LD need specialized assistance during the teaching and learning process' $168(69.1 \%)$, 'That the information collected about students with LD is used to determine their skill level' $153(63.0 \%)$, 'How to adjust sitting arrangements to the needs of the students with LD' $140(57.6 \%)$ and 'The various ways of identifying students with LD' 125 (51.4\%). In aggregate, very few out of the majority of the teachers $44.9 \%\left(n_{\text {responses }}=2074\right)$ had the knowledge to provide ESS to students with learning disabilities in inclusive settings.

Table5. Knowledge about students with learning disabilities (LD) in classrooms by background indicators

\begin{tabular}{|c|c|c|c|c|c|c|}
\hline \multirow[t]{2}{*}{ Indicators } & \multirow[t]{2}{*}{ Categories } & \multicolumn{3}{|c|}{$\begin{array}{l}\text { knowledge to provide educational support } \\
\text { services to students with learning disabilities in } \\
\text { inclusive settings } \\
\text { (Aggregated score: MRS) }\end{array}$} & \multirow[t]{2}{*}{$\mathbf{N}_{\text {responses }}$} & \multirow[t]{2}{*}{$\chi 2$-test } \\
\hline & & Yes & No & Undecided & & \\
\hline \multirow[t]{2}{*}{ Gender } & Male & $817(39.8 \%)$ & $929(45.3 \%)$ & $306(14.9 \%)$ & 2052 & \multirow{2}{*}{$\begin{array}{l}\chi 2=0.00 \\
\mathrm{df}=1 \\
\mathrm{P}=0.948\end{array}$} \\
\hline & Female & $1315(39.5 \%)$ & $1486(44.7 \%)$ & $524(15.8 \%)$ & 3325 & \\
\hline \multirow[t]{3}{*}{ Qualification } & DIPES I/PCEG & $740(44.3 \%)$ & $715(45.8 \%)$ & $217(13.0 \%)$ & 217 & \multirow{3}{*}{$\begin{array}{l}\chi 2=5.73 \\
\mathrm{df}=2 \\
\mathrm{P}=0.048\end{array}$} \\
\hline & $\begin{array}{l}\text { DIPES } \\
\text { II/PLEG }\end{array}$ & $1352(39.8 \%)$ & $1496(44.0 \%)$ & $553(16.3 \%)$ & 3401 & \\
\hline & B.A & $40(13.2 \%)$ & $204(67.1 \%)$ & $60(19.7 \%)$ & 304 & \\
\hline \multirow{3}{*}{$\begin{array}{l}\text { Working } \\
\text { experience } \\
\text { categorized }\end{array}$} & $1-5$ & $443(28.1 \%)$ & $815(51.7 \%)$ & $319(20.2 \%)$ & 1577 & \multirow{3}{*}{$\begin{array}{l}\chi 2=7.15 \\
\mathrm{df}=2 \\
\mathrm{P}=0.028\end{array}$} \\
\hline & $6-10$ & $658(46.2 \%)$ & $579(40.6 \%)$ & $188(13.2 \%)$ & 1425 & \\
\hline & $11+$ & $1031(43.4 \%)$ & $2021(43.0 \%)$ & $323(13.6 \%)$ & 2375 & \\
\hline \multirow[t]{2}{*}{ Categories } & Teachers & $2074(44.9 \%)$ & $1824(39.5 \%)$ & $719(15.6 \%)$ & 4617 & \multirow{2}{*}{$\begin{array}{l}\chi 2=0.00 \\
\mathrm{df}=1 \\
\mathrm{P}=0.986\end{array}$} \\
\hline & Inspectors & $341(44.9 \%)$ & $308(40.5 \%)$ & $110(14.5 \%)$ & 760 & \\
\hline
\end{tabular}


Knowledge to provide educational support services to students with learning disabilities in inclusive settings did not depend on gender because males (39.8\%) had almost equal level of knowledge with the females (39.5\%). Knowledge to provide ESS to learners with LD on the other hand significantly depended on qualification whereby holders of BA had the lowest weight (13.2\%) as compared to $44.3 \%$ for holders of DIPES I/PCEG and 39.8\% for holders of DIPES II/PLEG $(\mathrm{P}<0.05)$. It was equally realized that those with the lowest number of teaching experience years were the least knowledgeable with a proportion of $28.1 \%$, significantly lower as compared to $46.2 \%$ and $43.4 \%$ for those with 6 to 10 and 11 and above years of teaching experience $(\mathrm{P}<0.05)$. Teachers and inspectors had the same level of performance.

\subsection{Research Hypothesis Testing}

a) Null hypothesis (Ho): There is no significant relationship between teachers' knowledge and their ability to provide educational support services to students with LD in inclusive settings.

b) Alternative hypothesis (H1): There is a significant relationship between teachers' knowledge and their ability to provide educational support services to students with LD in inclusive settings.

Table6. Perceived relationship between teachers' knowledge and their ability to provide support services to students with $L D$ in inclusive settings

\begin{tabular}{|c|c|c|}
\hline & Spearman's rho & $\begin{array}{l}\text { Ability to provide educational support } \\
\text { services to students with learning disabilities } \\
\text { in inclusive settings }\end{array}$ \\
\hline \multirow{3}{*}{$\begin{array}{l}\text { Knowledge to provide educational } \\
\text { support services to students with learning } \\
\text { disabilities in inclusive settings }\end{array}$} & $\mathrm{R}$ & $0.917^{* *}$ \\
\hline & P-value & 0.000 \\
\hline & $\mathrm{N}$ & 243 \\
\hline
\end{tabular}

There was a high and positive significant correlation between teachers' knowledge and their ability to provide educational support services to students with learning disabilities in inclusive settings $(\mathrm{r}=0.917, \mathrm{P}<0.001)$ therefore implying that the more knowledge teachers acquire on inclusive practices, the better their ability to provide educational support services to students with learning disabilities in inclusive settings. The null hypothesis (Ho) was then rejected and the alternative hypothesis (H1) was retained.

\section{DISCUSSION}

This study examined the adequacy of secondary school teachers' knowledge to provide educational support services to students with learning disabilities. The results of the study revealed that teachers were not exposed to the knowledge of concepts related to inclusive education. Out of the ten concepts related to the provision of educational support services to students with learning disabilities, a majority of teachers and pedagogic inspectors showed little understanding of eight of them such as, inclusive education, learning disabilities, individual education plan (IEP), assistive technology, support services, differentiated instruction and curriculum adaptation. They had some knowledge only on special school and special teachers while inspectors extended their knowledge to special education.

The study further revealed that teachers do not know how to work with special teachers, coordinate group meetings, adapt curriculum to meet the needs of students with learning disabilities in their classrooms, do not know the meaning of assistive technology, how to plan lessons using individual educational plan (IEP) and how to adjust the pace off instruction and the content of lesson to accommodate learners with learning disabilities because they lack the necessary knowledge and skills to carry out the above function. The reason been that they have not been trained on trained on inclusive practices during their pre-service training nor have they received any through in-service training. Some of them desire that students with learning disabilities be placed in special institutions because that where they can be effectively learn and achieve their goals. Engelbrecht and Green (2001) and Price and Cole, (2009) emphasize that regular education teachers need to acquire the knowledge and skills of collaboration and effective teaching strategies if they have to effectively provide academic support services that are needed by students with learning disabilities in their classrooms

These results imply that government secondary grammar school teachers in Cameroon are not equipped with the relevant knowledge to provide educational support services to learners with 
learning disabilities in their classrooms. The reason given was that though they were professionally trained teachers, they training they receive was not to provide ESS to students with disabilities. The implication is that teachers need to be equipped with relevant knowledge in order to effectively provide educational support services to students with learning disabilities in their classrooms. The results indicate to curriculum planners the need to include inclusive education in teacher training programs so that teachers can adequately acquire the necessary knowledge during their pre-service education to function in inclusive environments. Moreover, the government may consider these areas to plan continued staff development activities for teachers who are already in the field teaching, since the results serve as the teachers' inventory of needs in as far as their training is concerned.

\subsection{Recommendations}

This study acknowledges that providing educational support services to students with learning disabilities in inclusive settings is a multifaceted and arduous task which depends on teachers who have had training along that line. In other words, the failure or success of providing educational support services to students with learning disabilities is a product of well trained teachers. This section therefore, makes recommendations to policy makers and stakeholders based on the question which this study raised and sought to provide answers.

1. To acquire the necessary knowledge secondary school teachers need to better provide educational support services to students with learning disabilities in inclusive classrooms, the findings of this study suggest that they need to be educated on inclusive practices.

2. For teachers already in the field teaching, they too need to be educated on inclusive education. The training could be carried out through seminars, workshops, short courses, or taking a leave of study to enroll into a special need program in the university of Buea. If regular teachers effectively attend seminars, workshops, short courses and even enroll into the university, then they would acquire the necessary knowledge to better support students with LD in their classrooms.

3. Research suggest that for teachers to meet the individual needs of students with learning disabilities in inclusive settings, they must have the skills to differentiate instruction, plan and implement the IEP, use assistive technological gadgets and many other. To acquire the needed skills, teachers could be trained. For this to work, the government could first of all organize trainthe-trainers workshop. This means that those who are responsible for training secondary school teachers (pedagogic inspectors) will first receive their training at designated venues at the national level through in-service training on inclusive practices. They can then organize seminars, workshops and in-service training for teachers to acquire the relevant knowledge that is needed to function effectively in inclusive settings.

4. To acquire the professional attitudes to effectively provide support to students with learning disabilities, teachers could make efforts to regularly pay visits to special schools and observe how the students are taught. Seminars and workshops which focus on hands on activities could equally be organized and specialists in special education or successful inclusive teachers and individuals with disabilities could be used as guest speakers to train teachers to develop professional attitudes which are needed to provide ESS to learners with learning disabilities.

\section{CONCLuding Remarks}

Research carried out on Teacher preparedness for inclusive education in Cameroon focus mostly on teachers' attitudes. Others dwell on principal, parents and other stakeholders. This study highlighted teachers' preparedness and called attention to learning disabilities in particular, the dominant disabilities in secondary school classrooms in the South West Region of Cameroon. This study recommended that secondary school teachers could be trained in inclusive practices to improve their ability to provide support to students with learning disabilities. The findings of the study could provide policy-makers some bases for the implementation of inclusive education in Cameroon. Teacher education has an important role in the formation of teachers' professional attitudes towards providing support to students with learning disabilities in their classrooms. In-service training should be organized in a way that can motivate teachers to attend and be willing to apply what they learn to the actual implementation of inclusion of students with learning disabilities. 


\section{REFERENCES}

Ackah, F. R., (2007). Teachers characteristics as predictors of attitude towards inclusive Education in the Cape Coast Metropolis of Ghana. International Journal of Special Education, 22(3), 38-46.

Abosi, C. O. (2003). Thoughts on an action plan for the development of inclusive Education in Africa: Division of international special education and services -National perspectives. Accessed February 20, 2015 from http://lists.cec.sped.org/int1/na1 over.htm1.

Agbenyega, J. S. \& Deku, P., (2011). Building new identities in teacher preparation for inclusive education in Ghana. Current Issues in Education, 14(1). Available from http://cie.asu.edu/

Avramidis, E., Bayliss, P., \& Burden, R. (2000). A survey into mainstream teachers' attitudes towards the inclusion of children with special educational needs in the ordinary school in one local education authority. Educational Psychology, 20(2), 191-211.

Baker, J. \& Zigmond, N. (1995). The meaning and practice of inclusion for children with Learning disabilities: Themes and implications from five cases. Journal of special Education. 22 (2), 163180.

Bandura, A. (1994). Self-Efficacy. In V. S. Ramachaudran (Ed.) Encyclopedia of human behavior, 4. NewYork: Academic Press, pp. 71-81

Bender, W. N., Vail, C. O., \& Scott, K. (1995). Teachers' attitudes toward increased mainstreaming: Implementing effective instruction for students with learning disabilities. Journal of Learning Disabilities, 28(2), 87-94.

Berry, R. (2010). Preservice and early career teachers' attitudes toward inclusion, instructional accommodations, and fairness: Three profiles. The Teacher Educator,Chmiliar, L., \& Cheung, B. (2007). Assistive technology training for teachers -Innovation and accessibility online. Developmental Disabilities Bulletin, 35(1), 18-28

De Graaf, G., Van Hove, G., \& Haveman, M. (2013). More academics in regular schools? The effect of regular versus special school placement on academic skills in Dutch primary school students with Down syndrome. Journal of Intellectual Disability Research, 57(1), 21-38.

De La Paz, S., \& MacArthur, C. (2003). Knowing the how and why of history: Expectations for students with and without learning disabilities. Learning Disability Quarterly, 26, 142-154

DeSimone, J. R., \& Parmar, R. S. (2006a). Issues and challenges for middle school mathematics teachers in inclusion classrooms. School Science and Mathematics, 106(8), 338-348.

Donovan, L., Green, T., \& Hartley, K. (2010). An examination of one-to-one computing in the middle school: Does increased access bring about increased student engagement? Journal of Educational Computing Research, 42, 423-441. doi:10.2190/EC.42.4.d

Dymond, S. K., Renzaglia, A. Gilson, C. L. \& Slagor, M. T. (2007). Defining access to The general curriculum for high school students with significant cognitive Disabilities. Research and Practice for Persons with severe Disabilities, 32(1), 1-15.

Edozie, I. \& Jacob, U. S. (2012). Issues and challenges in inclusive education practice. African Journal of Inclusive Education. Vol.1(1), 182-191,

Eklindh, K. (2000). The right of all children and young people to a good education in a unified school for all pupils. In: Meeting special and diverse educational needs: making inclusive education a reality.Ed. byH. Savolainen, H. Kokkala \& H. Alasuutari. Helsinki: Department for International Development cooperation \& Niilo Maki institute, 99-106. Accessed April 15, 2006 from http://www.eenet.org.uk/newsletters/news5/p16.shtm1

Hastings, R. P. \& Oakford, S. (2003). Student teachers' Attitudes towards the Inclusion of children with special needs. Educational Psychology, Vol. 23, No. 1.

Hetzroni \& Shrieber, 2004).

Hodkinson, A. (2005). Conceptions and misconceptions of inclusive education: A critical Examination of final year teacher trainees' knowledge and understanding of Leyser, Y., \& Tappendorf, K. (2001). Are attitudes and practices regarding mainstreaming changing? A case of teachers in two rural school districts. Education, 121(4), 751-760

Leyser, Y., Zeiger, T. \& Romi, S. (2011) 'Changes inself-efficacy of prospective special and generaleducation teachers: implication for inclusiveeducation.' International Journal of Disability, Development and Education, 58 (3),pp. 241-55. 
Teacher's Educational Support Services to Students with Learning Disabilities in Inclusive Educational Classrooms; The Case of Selected Secondary Grammar Schools in the South West Region of Cameroon

Li, D., Oneonta, S., \& Ji, H. (2010). Teaching students with disabilities in regular education classes: Perceptions of pre-service teachers from China and United States. Educational Research and Development, 13 (1), 62-69

Vogel, S.A., Holt, J.K., Sligar, S., \& Leake, E. (2008) Assessment of campus climate to enhance student success. Journal of Post-secondary Education and Disability, 21, 131

Vongalis-Macrow, A. (2007) I, Teacher: re-territorialization of teachers' multi-faceted agency in globalized education. British Journal of Sociology of Education. 28 (4): 425-439

Voss, J., \& Bufkin, L. (2011). Teaching all children: Preparing early childhood preservice teachers in inclusive settings. Journal of Early Childhood Teacher Education, 32(4), 338-354.

Wadlington, E. M., \& Wadlington, P. L. (2005). What educators really believe about dyslexia. Reading Improvement, 42(1), 16-33.

Wagner, M., Newman, L., Cameto, R., \& Levine, P. (2006). The academic achievement and functional. performance of youth with disabilities. A report from the National Longitudinal Transition Study-2 (NLTS2) (NCSER 2006-3000). Menlo Park, CA: SRI International

Wahlstrom, K. \& Loius, K. S. (2008). How teachers experience principal leadership: The Role of professional community, trust, efficacy, and shared responsibility, Educational Administration Quarterly, Vol. 44(4), 458-495. Accessed 29 march 2014

Wanzek, J., Vaughn, S., Wexler, J., Swanson, E., Edmonds, M., \& Kim, A. (2006). A synthesis of spelling and reading interventions and their effects on the spelling outcomes of students with LD. Journal of Learning Disabilities, 39, 528-543. doi:10.1177/00222194060390060501

Watson, A. H., Ito, M., Smith, R. O., \& Andersen, L. T. (2010). Effect of assistive technology in a public school setting. American Journal of Occupational Therapy, 64,18-29. http://dx.doi.org/ 10.5014/ajot.64.1.18

Wearmouth, J. Edwards, G. \& Richmond, R. (2000). Teachers' professional development to support inclusive practices. Journal of In-service Education, (26), 37-48.

Wehmeyer, M. L. \& Schwartz, M. (1997). Self-determination and positive adult outcomes: A followup study of youth with mental retardation or learning disabilities. Exceptional Children, 63, 245255.

Welch, M. (1995). Teacher education and the neglected diversity: Preparing educators to Teach Students with disabilities, Journal of Teacher Education, 45(5), 355-366.

Winters, C. A. (1997). Learning disabilities, crime, delinquency, and special education placement. Adolescence, 32. Retrieved February 2, 2015, from Questia.

Wendell, M. (2009) Planning for Educational Change Putting people and their contexts first. London: Continuum.

Winter, E. C. (2006). Preparing new teachers for inclusive schools and classrooms. Support for Learning, 21(2), 85-91

Winzer, M. (1999). Children with exceptionalities in Canadian classrooms $\left(5^{\text {th }}\right.$ ed.). Scarborought, ON: Prentice Hall.

Wood, J. W. (2002). Adapting instruction to accommodate students in inclusive settings $4^{\text {th }}$ edition. Upper Saddle River: Merril Prentice Hall.

Yuen, M. Westwood, P \& Wong, G, (2004). Meeting the needs of students with specific learning difficulties in the mainstream education system: The International Journal of Special Education 20, 1-75

Yuh, E. \& Shey, P. (2008). The Education of persons with special needs in Cameroon: A historical perspective, African Journal of Special Education, 1(1), 27-31.

Yuh, E. (2014). Supporting the Classroom Teacher to Understand and Teach Diverse Learners in the Classroom: African Journal of Special Education, vol. 2(1), 1-8.

Zigmond, N. \& Baker, J.M., (1995). The meaning and practice of inclusion for students with learning disabilities: Themes and implications from five cases. Accessed March $19^{\text {th }} 2015$ from http://rse.sagepub.com/content/20/2/114.refs

Zigmond, N. (2003). Where should students with disabilities receive special education. Journal of Special Education, November 2003 vol. 37 no. 3, 193-199

Zigmond, N., Kloo, A, \& Volonino, V. (2009). What, where and how? Special education in the climate of full inclusion. Exceptionality, 17,189-204. 


\section{AUTHOR'S BIOGRAPHY}

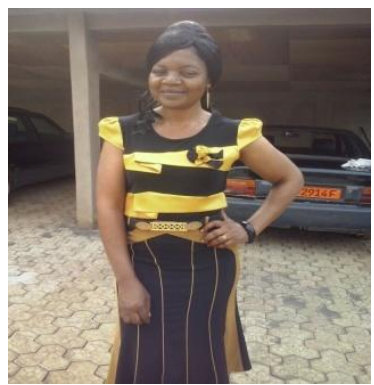

Dr Nchia Mary-Judith Yuoh Epse Mboge, is a teacher of special Needs Education at the University of Buea and Regional Pedagogic Inspector of Secondary Education at the Regional Delegation of Secondary Buea Cameroon. Nchia Mary-Judith Yuoh has a Ph.D in Special Needs Education with a concentration in Inclusive Education and Learning Disabilities. She has a Master Decree (M.Ed) in Curriculum Development, a Higher Teacher Grade I Diploma (DIPES II) in English Modern Letters and a Bachelor Decree (BA) in English Modern Letters. Among her numerous publications are:

1. Supervision of Instruction in Cameroon: Are Pedagogic Inspectors doing their Work?"

2. Investigating Teachers Attitudes in Inclusive Education: The Case of persons with learning disabilities

3. Students' Perception of Disabilities in the University of Buea

Dr. Nchia Mary-Judith Yuoh Epse Mboge is a renowned researcher working with: Foundation of Scientific Research, Community Based Rehabilitation and Advocacy on Inclusive Education (FORCAIE - Cameroon). 